\title{
Study on the stability of internal quality control sera for HIV/AIDS immunodiagnostic tests
}

\author{
Estabilidade dos soros para o controle de qualidade \\ interno de testes imunodiagnósticos de HIV/AIDS
}

Márcia Jorge Castejon ${ }^{1}$; Rosemeire Yamashiro² Camila Cardoso de Oliveira’3;

Daniel Granato ${ }^{4}$; Carmem Aparecida de Freitas Oliveira; ${ }^{5}$ Mirthes Ueda ${ }^{6}$

\begin{abstract}
Introduction: The use of reference materials in order to assure and perform the quality control of analytical measurements is a requirement in clinical laboratories. Objectives: Stability of serum samples, kept frozen at $-20^{\circ} \mathrm{C}$ for long-term storage and at varied temperatures during short periods, was evaluated by investigating the persistency of anti-human immunodeficiency virus (HIV) antibodies reactivity on enzyme-linked immunosorbent assay/enzyme immunoassay (ELISA/EIA), Western blot and indirect immunofluorescence assays. Method: The analyzed sera were part of serum panels (comprised of anti-HIV positive and negative samples), produced at the Immunology Center of Instituto Adolfo Lutz, which have been the reference specimens for producing the internal quality assurance sera of HIV/acquired immunodeficiency syndrome (AIDS) immunodiagnostic assays. Sera stability was assessed in samples stored at $-20^{\circ} \mathrm{C}$ for 56 weeks, and at various temperature conditions: from $2^{\circ} \mathrm{C}$ to $8^{\circ} \mathrm{C}$ (refrigerator), from $15^{\circ} \mathrm{C}$ to $25^{\circ} \mathrm{C}$ (room temperature), at $37^{\circ} \mathrm{C}$ (incubator) and at $-80^{\circ} \mathrm{C}$ (freezer) for 24 and 48 hours. The statistical analyses on HIV-negative serum samples (long-term storage) were significant $(\phi<0.05)$, and neither adverse effects on these samples as the occurrence of false-positive results nor false-negative results in HIV antibody positive sera were found in both studies. Conclusion: It was possible to conclude that the reference material remained stable for 48 hours at different temperatures (short-term) and it remained stable at $-20^{\circ} \mathrm{C}$ for 56 weeks (long-term).
\end{abstract}

Key words: stability; control serum; HIV antibodies; temperature; quality control.

\section{INTRODUCTION}

The regular procedure of running quality control samples alongside test samples to determine diverse analytes in several composites by the daily laboratory assays demands the use of reference materials ${ }^{(25)}$. The reference material (RM) is a crucial tool for controlling the several aspects of measuring quality, and has been employed for varied purposes, for instance, the internal quality control (IQC) of routine testing ${ }^{(15)}$. This parameter is remarkably significant for laboratories trying to achieve technical competence in accordance with the International Standards
Organization (IS0)/International Electrotechnical Commission (IEC) Guide $17025^{(1)}$.

The implementation of IQC in human immunodeficiency virus (HIV)/acquired immunodeficiency syndrome (AIDS) serologic diagnosis is helpful and beneficial to bring about the quality improvement of the final testing results; also, to detect the systematic and random errors during the assay performance and to identify the lot-by-lot variation of the respective diagnostic reagent kits.

Since 2009, the Central Laboratory of Instituto Adolfo Lutz (IAL) has been engaged in production and distribution of HIV

First submission on 18/02/13; last submission on 19/09/13; accepted for publication on 11/10/13; published on 20/02/14

1. Master's degree in Genetics and Evolution from Universidade Federal de São Carlos (UFSCar); scientific researcher III at Instituto Adolfo Lutz (IAL)-São Paulo.

2. Bachelor's degree in Biology from Universidade de Mogi das Cruzes (UMC); scientific researcher II at IAL-São Paulo.

3. Master's degree in Sciences in the Statistics Area from Universidade de São Paulo (USP); scientific researcher I at IAL-São Paulo.

4. Doctorate in Food Science from USP; scientific researcher I at IAL-São Paulo.

5. Master's degree in Sciences from Coordenadoria de Controle de Doenças da Secretaria de Estado da Saúde de São Paulo (CCD-SES/SP); scientific researcher VI at IAL-São Paulo.

6. Post-doctoral degree in Immunology from University of California; scientific researcher VI at IAL-São Paulo. 
negative and positive sera panels. These samples have been the reference materials for preparing the IQC samples to anti-HIV serologic testing (HIV IQC) by the laboratory units enrolled at the Internal Quality Control Program, coordinated by IAL ${ }^{(6,7,21)}$.

The RM production consists of several procedures, including processing the biological materials and splitting them into small portions, packing and manufacturing them. In addition, the RM manufacturer has to assure that the products at hand comply with the quality prerequisites, as the appropriate homogeneity and the appraised controlled stability. According to ISO Guide $34^{(17)}$, manufacturers have to prove products quality in order to get their validation and certification.

The use of stability evaluation assays in conjunction with homogeneity testing is fundamental for the RM certification process, as it is a crucial parameter to indicate the RM preservation status during storage at specific lengths of time and temperature conditions $^{(2,5)}$

The RM lasts for several years; therefore, their properties have to be consistent during this time. Usually, the RM is setup in quantity, which is enough to meet laboratories needs for an established time period, so it is of utmost importance to ensure that the produced materials preserve the stated stability ${ }^{(10)}$.

In order to ensure stability for several years, the suitable storage conditions have to be examined by stability testing for long periods, even before the product becomes available on the market. This is the mostly effective strategy for collecting the needed data to assess the RM shelf life ${ }^{(25)}$

The Biological sample preservation demands the improvement of methodologies for performing long-term storage, what enables their efficient usage. Concerning biological sample transportation, preservation and storage, the quality management system of good technical practice has been developed to ensure and maintain the stability of these materials ${ }^{(16,24)}$. The suitable task would be to acquire knowledge on the deterioration rate of the concerned compound during the pertinent period ${ }^{(22)}$.

The stability study is performed not only to assess measurement uncertainty associated with the material steadiness, but also to specify the precise storage and transportation conditions. Sample handling during shipment, even under specific and suitable conditions, might differ from that in storage environments, because during transportation the sample is vulnerable to potential external factors, such as temperature change. For this reason, it is pivotal to understand what may occur to samples if some variations take place in the maintenance of adequate conditions: it is recommended to carry out a short-term stability study ${ }^{(2,19,23)}$.
During the RM shipment, samples are susceptible to the effects of temperature, length of time, mechanical shock, among other factors. Thus, it is remarkably important to assess the effects of the transportation system on the quality of laboratory results ${ }^{(12)}$. In some circumstances, it is not possible to maintain the appropriate conditions for assuring RM stability during shipment; in this case, it is recommended to take account of extra uncertainty related to the properties values ${ }^{(2)}$.

In order to carry out the short-term stability evaluation study, the RM is stored at varied temperatures aiming at elucidating whether any degradation may occur in the course of transportation. The study is usually of short duration, not longer than four weeks. Shipment conditions have to be chosen to ensure that the influence of short-term stability is negligible ${ }^{(19)}$.

High-level stability is fundamental, and this characteristic is expected for any biological product ${ }^{(18)}$; therefore, the manner a biological sample is prepared, transported and stored gives support to its stability and also to getting accurate results in analytical assays ${ }^{(26)}$. The care quality placed on the RM storage at an adequate temperature, since the beginning of sample preparation, will minimize the probability of degradation ${ }^{(19)}$.

\section{OBJECTIVE}

The present study was carried out to identify the effects of temperature on sera stability during sample storage and shipping, by assessing anti-HIV antibodies reactivity using sensitive and specific immunodiagnostic assays.

The major objective of the present investigation was to ensure sera stability to guarantee quality of the reference materials produced by Central IAL and distributed to laboratories taking part in the IQC Program so that they are able to prepare their HIV IQC samples.

\section{METHOD}

The serum samples analyzed in this study were prepared and established as reference materials for sera panels, constituted by HIV antibody-positive and antibody-negative samples, and employed as internal quality control (HIV IQC) in specific serologic assays. These sera were obtained by processing the plasma samples donated by a blood bank, and by using the thrombin technique ${ }^{(6}$ ${ }^{21)}$. The homogenized sera were dispensed (1 $\mathrm{ml}$ volume) into cryotubes, which were identified and stored at $-20^{\circ} \mathrm{C}$. 
The sera panels were composed by using the standard operational procedures established by HIV/AIDS Laboratory$\mathrm{IAL}^{(21)}$, in accordance with the Laboratory Good Practice Norms for distributing sera into aliquots, packing and cryotube labeling ${ }^{(20)}$.

By means of immunodiagnostic reagent kits of enzymelinked immunosorbent assay/enzyme immunoassay (ELISA/ EIA), indirect immunofluorescence assay (IFA) and Western blot (WB) assay for HIV antibodies detection, employed at HIV/AIDS Laboratory-Immunology Center (IMC)/IAL, the serum samples were characterized as to anti-HIV reactivity.

The HIV antibody-negative and antibody-positive sera samples were numbered according to the sequential enumeration previously established for serum panel lots produced at IAL (IMC/ IAL). Six serum lots were composed as previously described ${ }^{(8)}$ :

- two HIV-negative serum lots: numbers 063 and 065;

- two HIV strongly positive serum lots: numbers 067 and 075;

- two HIV-positive serum lots (numbers 061 and 067) diluted in negative sera for setting IQC (HIV weakly positive). These serum lots were numbered according to the positive sera employed - IQC 061 and IQC 067.

By following the procedure recommended by the technical manual ${ }^{(21)}$, the optimal dilution of serum samples to detect antiHIV antibody was determined for setting up the positive IQC for ELISA/EIA, IFA and WB methodologies, in conformity with the technique standardized at HIV/AIDS Laboratory-IMC/IAL.

The optimal dilution to be used as IQC for running the ELISA/EIA - Vironostika HIV Uni-Form Plus 0 - Biomérieux was equivalent to that one showing the optical density (OD) value in the range from 1.5 to 4.5 times the test cut off (CO) value ${ }^{(21)}$.The standardized dilution for WB and IFA was equivalent to that last one of a sequence of serum dilutions, in which the HIV antibody positive reactivity pattern was still discernible.

In order to prepare HIV weakly positive samples, the following dilutions were established: IQC HIV 061 diluted at 1:60,000 for running ELISA, 1:100 for WB and at 1:4 for IFA; and IQC HIV 067 diluted at 1:20,000 for ELISA, 1:400 for WB and at 1:8 for IFA.

Serum flasks were randomly selected to compose the sample subsets for assessing the short-term and long-term stability protocols by using the Microsoft Office Excel Program (Microsoft Corp., Redmont, WA, USA). The serum flasks analyzed in this study were stored at $-20^{\circ} \mathrm{C}$.

Stability alteration in the selected samples was evaluated by investigating the occurrence or the absence of variation in the analyte reactivity (that is positivity or negativity to HIV antibody) in ELISA/EIA - Vironostika HIV Uni-Form Plus 0 (Biomérieux SA, France), in indirect immunofluorescence technique - HIV-1 IFA (BioManguinhos-Fundação Oswaldo Cruz [FIOCRUZ], Brazil) and in Western blot assay - Cambridge Biotech HIV-1 (Maxim Biomedical, Inc., USA). These assays were performed following the procedures recommended by their respective immunodiagnostic kit manufacturers. The laboratory equipments used to perform serologic assays were: ELISA/EIA - automatic plate washer (Columbus Plus); microplate incubator (Model 5000) and automatic ELISA microplate reader (230/2001) and IFA fluorescence microscope (0lympus BX60).

The C0 values were determined at every ELISA/EIA running, and the results were expressed in the value corresponding to the $\mathrm{OD} / \mathrm{CO}$ ratio found in the respective testing; therefore, the methodology variation effects were minimized.

The fluorescence intensity in HIV-IFA was determined by comparing the observed results with that reactivity detected in the positive control sample enclosed in the commercial HIV assay kit, and also in the HIV-IFA IQC (HIV weakly positive serum). These control samples have been routinely included at every HIV-IFA test running. The following analysis criteria were settled on: $(3+)$ reactivity for fluorescence intensity equal or higher than that showed by positive control included in the diagnostic kit; (2+) reactivity for weak fluorescence equal to that detected in HIV-IFA IQC; (1+) weaker fluorescence than that found in the positive control sample; and (0) absence of fluorescent reactivity.

Western blot results were analyzed by visual classification of intensity in gp160, gp120, p66, p55, p51, gp41, p31, p24 and p17 bands. Also, band reactivity was determined by comparison with the p24 band shown by weakly positive control serum inserted in the respective diagnostic kit. The following result criteria were established: $(1+)$ weak reactivity (p24 band lower intensity than that found in the control serum); $(2+)$ reactive intensity equal or higher than control serum, and (0) absence of reactive bands ${ }^{(11)}$.

Two kinds of stability variation were assessed: a long-duration study, considering the storage length of time and the shelf life, the material stability by measuring the sample property value and in association with time; a short-duration study, in which samples were exposed to diverse temperatures to simulate transportation conditions $^{(2,5)}$.

\section{Long-term stability - ELISA/EIA}

The RM employed for setting HIV IQC was stored at $-20^{\circ} \mathrm{C}$ in compliance with the technical manual ${ }^{(21)}$. The RM samples were prepared under identical conditions, but they were analyzed 
at different times, and in accordance with ISO Guide $35^{(2)}$, what means that the classic study was conducted. This study was carried out for 56 weeks (392 days) to assess stability of six stored serum lots taking into account the previous information on sample stability.

Randomized sampling was done to select four cryotubes of each serum lot to be used to monitor the long-term stability (shelf life). These sera were analyzed at four specific lengths of time, that is, $20,33,51$ and 56 weeks from the date the samples were stored at $-20^{\circ} \mathrm{C}$. At every established length, one cryotube of each serum lot was picked. Then, samples were examined in triplicate, and the results were compared with those reactivity profiles previously characterized by means of the three above-mentioned anti-HIV detecting immunodiagnostic assay modalities. The respective sera were considered reference samples that corresponded to the storage time zero.

In order to analyze data related to the long-term study, the results from ELISA/EIA were firstly subjected to Shapiro-Wilk, Levene and Grubbs tests with 95\% confidence ${ }^{(9)}$. Then, a simple regression analysis was made in conjunction with the one-factor (one way) analysis of variance (ANOVA $)^{(2,3,9)}$. If the regression line inclination is not significant $(\phi>0.05)$, the property value is independent of time, therefore the material proves to be stable. In order to check for false-negative results, the data on HIV-negative samples were evaluated by regression analysis and one-factor ANOVA.

From the regression and ANOVA data, the estimate of uncertainty inherent in long-term stability (Ults) was calculated by multiplying the inclination standard error value by the evaluated time (expressed in weeks), and the shelf life was estimated using the prediction interval at $95 \%$ confidence.

The shelf life of the reference materials was estimated using the interval prediction, with 95\% confidence. All the statistical analyses were performed using the software Statistica v.11 (StatSoft, Tulsa, OK, USA) and Microsoft Office Excel v. 2010 (Microsoft Corp., Redmont, WA, USA).

\section{Short-term stability - ELISA/EIA}

The shipment of RM to the laboratory units enrolled in the IQC Program of IAL followed the procedures established in the technical manual ${ }^{(21)}$. The serum samples are packed in a proper thermal box containing dry ice. In this condition, the temperature stays at lower degrees than $-20^{\circ} \mathrm{C}$ (varying from $-50^{\circ} \mathrm{C}$ to $-80^{\circ} \mathrm{C}$ ) and for no longer than 24 hours, in order to preserve the biological characteristics of products, as during this period the ice is still maintained at low temperature and in an adequate shipping conditions.

The isochronous stability study was performed by exposing the RM to different temperatures for 48 hours. This procedure was carried out to investigate an eventual occurrence of adverse effects on the anti-HIV antibodies reactivity in sera of the six different lots during material shipment ${ }^{(2)}$.

In order to simulate transportation conditions, 17 sera cryotubes of each lot were randomly selected; one flask from each sample lot was left frozen at $-20^{\circ} \mathrm{C}$ (reference temperature). The other 16 serum flasks (test samples) were kept at different temperature conditions, from $2^{\circ} \mathrm{C}$ to $8^{\circ} \mathrm{C}$ (refrigerator), from $15^{\circ} \mathrm{C}$ to $25^{\circ} \mathrm{C}$ (environment), at $37^{\circ} \mathrm{C}$ (incubator), and at $-80^{\circ} \mathrm{C}$ (freezer), for previously defined 24-hour and 48-hour periods ${ }^{(2)}$.

After the serum samples were completed frozen at $-20^{\circ} \mathrm{C}$ (time zero), eight cryotubes of each lot were taken from freezer, and each pair of sample flasks were stored at every one of the four above mentioned temperatures for 48 hours. At the $24^{\text {th }}$ hour of storage at different temperatures, the same procedure was performed in the other eight cryotube samples that had remained in the freezer.

At the end of the 48-hour storage procedure, the respective samples and those corresponding to the 24-hour storage were tested on HIV antibody reactivity in triplicate. The reference material of each lot (kept at $-20^{\circ} \mathrm{C}$ ) was run in the same assay and under repeatability conditions, in order to reduce the dispersion of points in reference to time ${ }^{(2,27)}$.

For the short-term study, the ELISA/EIA results were firstly checked for normality, homogeneity of variance and outlier values by using the Shapiro-Wilk, Levene and Grubbs tests with 99\% confidence. Then, the one-factor variance analysis ${ }^{(3,9)}$ was performed to observe differences in the mean values of $\mathrm{OD} / \mathrm{CO}$ ratio in the assayed samples. In order to check for false-negative results, the data on HIV-negative samples were considered by regression analysis and one-factor ANOVA.

This study was approved by the Ethics Committee on Human Research of the IAL $\left(n^{0} 046 / 2010\right)$.

\section{RESULTS}

Serum samples of lots 067 and 075 (anti-HIV strongly reactive) showed positivity higher than the established maximum detection value $(\mathrm{OD}>3.000)$ in ELISA plate spectrophotometer - Organon Teknika Biomérieux - Reader 230. For this reason, 
regression analysis could not be done. Nevertheless, the statistical analyses were performed for the results obtained from weakly positive samples (IQC 061 and 067) which showed OD/C0 ratio values from 1.5 to 4.5 times the cut off value.

\section{Long-term stability}

With the purpose of establishing parameters to evaluate antiHIV antibody reactivity in samples stored for a long term, the serum samples (time zero) were previously characterized by means of the same immunodiagnostic assays, which were employed along with this investigation. The characteristics of anti-HIV antibody reactivity detected in the selected serum samples for this study were described in Table $\mathbf{1}$.

By analyzing the results obtained by Shapiro-Wilk, Levene and Grubbs test, with 95\% confidence, data were normally distributed, variances were homogeneous (homoscedasticity), and no outlier was detected, which are basic premises for regression analysis and ANOVA application.

The data resulting from linear regression analysis in conjunction with ANOVA and the uncertainty associated with stability were shown in Table 2.

Aiming at assessing sample stability at settled time intervals ( 56 weeks), the $p$-value of regression inclination was calculated. The IQC 067 and IQC 061 sera showed the inclination of the regression line undistinguishable from zero $(\phi>0.05)$; consequently, the weakly positive samples were regarded as stable for at least 56 weeks when stored at $-20^{\circ} \mathrm{C}$. Nevertheless, the negative sera 063 and 065 showed $p<0.05$ and negative line inclination, what, according to the statistic point of view, means instability.

For these negative sera, the mean value of $\mathrm{OD} / \mathrm{CO}$ ratio at time zero was higher than those means found in the course of time. These results were expected as the serological tests were carried out at different periods of time (classical study). No changes in the laboratory assays readings were found, and the results remained as non-reactive samples; in compliance with the criteria established by the diagnostic kit manufacturer, the sera were rated as non-reactive because the $\mathrm{OD} / \mathrm{C} 0$ rations were $<1.0$. Besides, the negativity of these sera was confirmed by Western blot and IFA assays.

Regarding IQC 061 and IQC 067 sera, the validity term of nearly 80 weeks was defined by means of prediction intervals with 95\% confidence of regression lines; during this period of time, the interval limits (from 1.5 to 4.5 times the cut off value) did not exceed the allowed maximum and minimum values for $\mathrm{OD} / \mathrm{CO}$ ratios.

No significant alteration on the reactivity related to the band presence and color intensity was observed in samples stored until 56 weeks by analysis in Western blot test, and when the results were compared with the bands detected in the previous characterization

TABLE 1 - Anti-HIV antibody reactivity in ELISA/EIA, HIV-1 IFA and HIV-1 WB of serum samples used as reference material for conducting the long-term study

\begin{tabular}{|c|c|c|c|c|}
\hline \multirow{2}{*}{ Sera } & \multicolumn{4}{|c|}{ Results } \\
\hline & ELISA/EIA OD/CO & IFA & WB & Interpretation \\
\hline 063 & 0.44 & 0 & 0 & Negative \\
\hline 065 & 0.42 & 0 & 0 & Negative \\
\hline 067 & 15.23 & $3(+)$ & $\begin{array}{l}\text { gp160, gp120, p66, p55, p51, } \\
\text { gp41, p31, p24, p17* }\end{array}$ & $\begin{array}{c}\text { HIV positive } \\
\text { (strongly reactive) }\end{array}$ \\
\hline 075 & 15.23 & $3(+)$ & $\begin{array}{l}\text { gp160, gp120, p66, p55, p51, } \\
\text { gp41, p31, p24, p17* }\end{array}$ & $\begin{array}{c}\text { HIV positive } \\
\text { (strongly reactive) }\end{array}$ \\
\hline IQC 061 & 2.4 & $2(+)$ & $\begin{array}{l}\text { gp160 (2+), gp120 (2+), } \\
\text { p66 (1+), p51(1+), gp41 } \\
(2+), \text { p31 (1+), p24 (1+) }\end{array}$ & $\begin{array}{c}\text { HIV positive } \\
\text { (weakly reactive) }\end{array}$ \\
\hline IQC 067 & 2.33 & $2(+)$ & $\begin{array}{c}\text { gp160 (2+), gp120 (2+), } \\
\text { p66 (2+), gp41 (1+), p24 } \\
(1+), \text { p17 }(1+),\end{array}$ & $\begin{array}{c}\text { HIV positive } \\
\text { (weakly reactive) }\end{array}$ \\
\hline 063 & 0.44 & 0 & 0 & Negative \\
\hline
\end{tabular}

HIV: buman immunodeficiency virus; ELISA: enzyme-linked immunosorbent assay; EIA: enzyme immunoassay; IFA: indirect immunofluorescence assay; WB: western blot; OD: optical density; CO: cut off; IQC: internal quality control; gp: glycoprotein band; p: protein band.

IFA: (0) no fluorescence, $(2+)$ weakly reactive fluorescence, $(3+)$ strongly reactive fluorescence.

WB: (0) absence of bands, (1+) weak intensity, (2+) strong intensity.

*All of the bands showed strong intensity (2+). 
TABLE 2 - Raw data related to OD/C0 results by analyzing sera lots at different periods of time (weeks) for studying long-term stability

\begin{tabular}{|c|c|c|c|c|}
\hline Time (weeks) & 063 & 065 & IQC 061 & IQC 067 \\
\hline 0 & 0.442 & 0.416 & 2.404 & 2.329 \\
\hline 0 & 0.431 & 0.411 & 2.466 & 2.389 \\
\hline 0 & 0.437 & 0.426 & 2.32 & 2.275 \\
\hline 20 & 0.249 & 0.219 & 2.112 & 2.515 \\
\hline 20 & 0.249 & 0.231 & 1.964 & 1.846 \\
\hline 20 & 0.26 & 0.237 & 2.095 & 2.799 \\
\hline 33 & 0.275 & 0.297 & 2.732 & 2.725 \\
\hline 33 & 0.268 & 0.283 & 2.21 & 3.217 \\
\hline 33 & 0.261 & 0.275 & 2.341 & 3.087 \\
\hline 51 & 0.256 & 0.25 & 2.122 & 2.167 \\
\hline 51 & 0.256 & 0.276 & 2.429 & 2.154 \\
\hline 51 & 0.231 & 0.244 & 2.077 & 2.622 \\
\hline 56 & 0.285 & 0.306 & 1.924 & 2.535 \\
\hline 56 & 0.299 & 0.285 & 1.965 & 2.285 \\
\hline 56 & 0.271 & 0.264 & 2.319 & 2.347 \\
\hline Mean & 0.298 & 0.295 & 2.232 & 2.486 \\
\hline Variation coefficient (\%) & 25 & 23 & 10 & 15 \\
\hline Inclination coefficient & -0.002 & -0.002 & -0.003 & 0.001 \\
\hline Standard error & 0.001 & 0.001 & 0.003 & 0.005 \\
\hline$p$ value (ANOVA) & 0.003 & 0.016 & 0.232 & 0.916 \\
\hline Confidence intervals $95 \%$ & $(-0.004 ;-0.001)$ & $(-0.003 ; 0.000)$ & $(-0.009 ; 0.003)$ & $(-0.010 ; 0.011)$ \\
\hline Ults (\%) & 19 & 19 & 8 & 11 \\
\hline Estimated shelf life (weeks) & $*$ & $*$ & 80 & 80 \\
\hline
\end{tabular}

OD: optical density; CO: cut off; IQC: internal quality control; ANOVA: analysis of variance; HIV: human immunodeficiency virus; Ults (\%): standard uncertainty inherent in long-term stability expressed in percentage for a period of 56 weeks.

*Once the material is HIV negative, the regression analysis showed the values decrease with time; therefore, there is no need to estimate the shelf life.

(Table 1). Also, no reactivity variations concerning the fluorescence intensity or absence parameters were found in HIV positive and negative sera when these samples were tested by the IFA assay.

\section{Short-term stability}

Table 3 shows the ELISA/EIA results found in the simultaneous measurement of samples stored at different temperatures and of the reference sera (stored at $-20^{\circ} \mathrm{C}$ ), which were analyzed under repeatability conditions. Overall, the data showed to be normally distributed, presented homogeneity of variance and some outliers were detected.

Afterwards, ANOVA was employed to verify whether the mean values of $\mathrm{OD} / \mathrm{C} 0$ ratios found in sera differed among themselves at 99\% confidence. These results are shown in Table 4.
The data shown in Table 4 indicate the stability of sera stored at different temperatures, once $p$-values higher or equal 0.01 were attained. For this reason, it is possible to assume that the RM was stable not only at the reference temperature $\left(-20^{\circ} \mathrm{C}\right)$, but also at the other temperatures simulating those taking place during transportation for a period of 48 hours.

By analyzing the sera stored at different temperatures and lengths of time by IFA assay, no reactivity alteration was found on the fluorescence intensity or in its non-reactivity outcomes in HIV positive and negative sera, and in comparison with the reference samples. In addition, these samples did not show any reactivity alteration in Western blot either on band presence or on band intensity, in compliance with the standard reactivity shown by the reference samples. Thus, it means that the results remained the same as those found in the previous serum characterization shown in Table 1. 
TABLE 3 - Results expressed by 0D/C0 ratio in ELISA/EIA, by calculating the means of the sample triplicate values detected in the reference sera and the test samples

\begin{tabular}{|c|c|c|c|c|c|c|c|c|c|}
\hline \multirow[t]{2}{*}{ Sera } & \multicolumn{2}{|c|}{$\begin{array}{l}\text { Refrigerator } \\
\quad\left(2-8^{\circ} \mathrm{C}\right)\end{array}$} & \multicolumn{2}{|c|}{$\begin{array}{c}\text { Incubator } \\
\left(37^{\circ} \mathrm{C}\right)\end{array}$} & \multicolumn{2}{|c|}{$\begin{array}{l}\text { Environment } \\
\left(15^{\circ} \mathrm{C}-25^{\circ} \mathrm{C}\right)\end{array}$} & \multicolumn{2}{|c|}{$\begin{array}{l}\text { Freezer } \\
\left(-80^{\circ} \mathrm{C}\right)\end{array}$} & \multirow{2}{*}{$\begin{array}{l}\text { Reference sera } \\
\quad\left(-20^{\circ} \mathrm{C}\right)\end{array}$} \\
\hline & 24 hours & 48 hours & 24 hours & 48 hours & 24 hours & 48 hours & 24 hours & 48 hours & \\
\hline 063 (flask 1) & 0.302 & 0.266 & $0.497^{*}$ & 0.24 & 0.327 & 0.298 & 0.333 & 0.291 & 0.311 \\
\hline 063 (flask 2) & 0.302 & 0.266 & 0.29 & 0.253 & 0.32 & 0.284 & 0.324 & 0.278 & \\
\hline 065 (flask 1) & 0.28 & 0.26 & 0.222 & 0.272 & 0.273 & 0.304 & 0.258 & $0.316^{*}$ & 0.286 \\
\hline 065 (flask 2) & 0.248 & 0.264 & $0.248^{*}$ & 0.251 & 0.28 & 0.309 & 0.251 & 0.269 & \\
\hline $\begin{array}{l}\text { IQC } 061 \\
\text { (flask 1) }\end{array}$ & 2.302 & 2.23 & 2.303 & $2.231^{*}$ & 2.338 & 2.251 & 2.411 & 2.482 & 2.086 \\
\hline $\begin{array}{l}\text { IQC } 061 \\
\text { (flask 2) }\end{array}$ & 2.172 & 2.394 & 2.312 & 2.333 & 2.162 & 2.384 & 2.278 & 2.518 & \\
\hline $\begin{array}{l}\text { IQC } 067 \\
\text { (flask 1) }\end{array}$ & 2.711 & 2.391 & 2.551 & 2.253 & 2.582 & 2.458 & 2.524 & 2.444 & 2.243 \\
\hline $\begin{array}{l}\text { IQC } 067 \\
\text { (flask 2) }\end{array}$ & 2.398 & 2.324 & 2.553 & 2.135 & 2.253 & $2.982^{*}$ & 2.387 & 2.269 & \\
\hline
\end{tabular}

OD: optical density; CO: cut off; ELISA: enzyme-linked immunosorbent assay; EIA: enzyme immunoassay; IQC: internal quality control. *Outliers detected in one of the triplicate reactions, with 99\% confidence (Grubbs).

TABLE 4 - Probability values from ANOVA analysis by comparing the mean values found in sera stored at different temperatures and lengths of time

\begin{tabular}{ccccc}
\hline \multirow{2}{*}{ Sera } & \multicolumn{4}{c}{ Temperature } \\
\cline { 2 - 5 } & $\begin{array}{c}\text { Refrigerator } \\
\left(2-8^{\circ} \mathrm{C}\right)\end{array}$ & $\begin{array}{c}\text { Environment } \\
\left(15-25^{\circ} \mathrm{C}\right)\end{array}$ & $\begin{array}{c}\text { Incubator } \\
\left(37^{\circ} \mathrm{C}\right)\end{array}$ & $\begin{array}{c}\text { Freezer } \\
\left(-80^{\circ} \mathrm{C}\right)\end{array}$ \\
\hline 063 & 0.1 & 0.31 & 0.29 & 0.15 \\
065 & 0.15 & 0.08 & 0.02 & 0.17 \\
IQC 061 & 0.03 & 0.03 & 0.03 & 0.02 \\
IQC 067 & 0.17 & 0.37 & 0.02 & 0.27 \\
\hline ANOVA: analysis of variance; IOC: internal quality control.
\end{tabular}

\section{DISCUSSION}

Although the present study has indicated that sera stability maintenance is a parameter to ensure RM quality, it is also indispensable to take into consideration the diverse factors that cause effects on the concentration of some specific components during sample storing and analyzing. Depending on the measurement methodology selected for conducting the investigation, an effect might occur on the results of the evaluated analyte, which is prone to degradation. Therefore, combining the material stability knowledge and the adequate methodology selection is crucial to achieve accurate and reliable results ${ }^{(14)}$.

Analyzing the samples from Janus Serum Bank, Gislefoss et $a l .{ }^{(13)}$ showed that immunoglobulins $\mathrm{G}$ and $\mathrm{E}$ (IgG and IgE) were relatively stable to the long-term storage procedure. And those data resulting from applying different methodologies fit in with the rationale of the present study.
It is worthy emphasizing that in order to get accurate results some cautions have to be taken in preserving biological sample quality during the storing process. When the storing conditions are modified, these alterations definitely cause effect on sample quality, and they could even reflect on the robustness of analytical methodologies. Thus, the instability of a biological sample component is a potential cause for invalidating research results ${ }^{(14)}$.

Aiming at conducting the long-term stability study, the serum samples were analyzed by the same technician, but the serological assays were performed at different periods of time (classical study) $)^{(2)}$. These facts might be responsible for inducing variability in negative serum results (reproducibility alteration), what is detected by the coefficient of variation, and is generated in an inversely proportional way to the methodology precision. On the other hand, precision varies according to the investigated substance concentration; the lower the concentration is, the higher the coefficient of variation is ${ }^{(4)}$.

The serum samples (long-term stability study) were prepared at the same time under the same conditions, but they were analyzed by means of different immunodiagnostic tests at each established period of time. The study was carried out under intermediate precision conditions, and stability was learned at each analysis; therefore, uncertainty was high and the unstable measuring system was included in uncertainty estimation.

A correlation between the estimate and the RM shelf life was calculated, and it was possible to observe that the longer the shelf life is, the higher the value of uncertainty related to stability is. In order to confirm the stability prognosis of IQC 061 and IQC 067 
sera, it would be necessary to monitor the sera during an estimated period of nearly 80 weeks.

Laboratory technicians' vast knowledge on the pre-analytical proceeding is relevant to avoid errors and variations in the final results and, consequently, not to compromise the clinical diagnosis and medical conduct. Inclusion of internal quality control samples in every specific serological assay carried out at laboratories is crucial. Considering that these samples are weakly reactive, any changes in their components are easily noticed in the assay results. The stability of sera is evidenced by analyzing the reactivity of specific antibodies in the internal quality control samples.

\section{CONCLUSION}

In order to certify the reference material for the IQC Program by monitoring temperature, during the sample shipment and storing period of time (shelf life), strategies for preserving the performance of the biological product are fundamental, when they are employed in accordance with specifications. In this context, temperature has to be continuously monitored, and the recommendations for storing and transporting the reference material should be strictly followed.

In the bibliographic survey performed for the conduction of this study, few citations were found on serum stability analysis by assessing antibody reactivity. Similarly as done for performing the serum homogeneity study (article in press), the methodologies employed in the chemical area were adapted and used for being suitable to accomplish the biological samples stability testing in the present investigation.

With respect to the short-term stability study, it is possible to conclude that the candidate RM remained stable after 48 hours at different temperatures (refrigerator, room temperature, incubator and freezer). The long-term-study revealed that the candidate $\mathrm{RM}$ remained stable at a temperature of $-20^{\circ} \mathrm{C}$ for 56 weeks, with uncertainty in the range of $8 \%-11 \%$. Indeed, the estimated shelf life of the materials was 80 weeks

This study will provide a helpful approach for other investigators to estimate the effects of long- and short-term storing on the stability of analyte(s) contents in biological samples. The practice of product storing affects the concerned analytes even if they have been handled and preserved under the ideal conditions, chiefly on the outcome of how the biological samples in a specific study have been effectively handled and stored. Considering that the results are dependent on various factors other than temperature, such as the unavoidable delay in sample processing, fails in storing conditions, lack of equipment calibration, among others, the occurrence of data variations in different studies is expected.

\section{ACKNOWLEDGEMENTS}

This study had financial support from IAL-Central Laboratory, Coordenadoria de Controle de Doenças da Secretaria de Estado da Saúde de São Paulo (CCD/SES-SP). We would like to thank Dra. Alice M. Sakuma and Dra. Maria Cristina Duran, of the Reference Material Center of IAL-Central Laboratory, Prof. Dr. José Carlos Olivieri, of Consulting and Training in Business Management, André Rodrigues de Campos and Maria Cristina Sartorato, of the Immunology Center of IAL-Central Laboratory, for their technical support. Thanks are also due to Associação Beneficente para Coleta de Sangue (COLSAN) of São Paulo-SP and Fundação Hemocentro de Ribeirão Preto of Faculdade de Medicina of Universidade de São Paulo - Campus Ribeirão Preto, São Paulo, for providing the discarded plasma samples.

\section{RESUMO}

Introdução: A utilização de materiais de referência para assegurar e desempenhar o papel de controle de qualidade das medições analíticas é requisito em laboratórios clínicos. Objetivo: Opresente estudo avaliou a estabilidade das amostras de soro, armazenadas a-20 $2{ }^{\circ}$ por um longo período de tempo e durante curto prazo em diferentes temperaturas, quanto à invariabilidade da reatividade de anticorpos contra o vírus da imunodeficiência bumana (HIV), por meio de enzyme-linked immunosorbent assay/enzyme immunoassay (ELISA/EIA), Western blot e imunofluorescência indireta. Método: As amostras analisadas foram provenientes de painéis de soros (constituídos de amostras anti-HIV positivo e negativo), produzidos no Centro de Imunologia do Instituto Adolfo Lutz (IAL), os quais têm sido material de referência para o preparo de amostras do controle de qualidade interno de testes imunodiagnósticos de HIV/sindrome da imunodeficiência adquirida (AIDS). A avaliação da estabilidade dos soros foi efetuada 
em amostras armazenadas $a-20^{\circ} \mathrm{C}$ por 56 semanas e nas diferentes condiçoes de temperaturas: de $2^{\circ} \mathrm{C}$ a $8^{\circ} \mathrm{C}$ (geladeira), de $15^{\circ} \mathrm{C}$ a $25^{\circ} \mathrm{C}$ (ambiente), $37^{\circ} \mathrm{C}$ (estufa) e $-80^{\circ} \mathrm{C}$ (freezer), durante 24 e 48 horas. Os resultados das análises de tendência das amostras de soro HIV negativo (armazenamento de longo prazo) foram significantes ( $\mathrm{p}<0,05)$ e nenbum efeito adverso foi observado nessas amostras, como a ocorrência de resultados falso-positivos, tampouco foram detectados resultados falso-negativos em amostras de soro positivas para deteç̧ão de anticorpos anti-HIV em ambas as avaliações. Conclusão: Foi possivel concluir que o material de referência manteve-se estável por 48 horas nas diferentes temperaturas (curto prazo) e permaneceu estável a $-20^{\circ} \mathrm{C}$ por 56 semanas (longo prazo).

Unitermos: estabilidade; soro controle; anticorpos anti-HIV; temperatura; controle de qualidade.

\section{REFERENCES}

1. ABNT. Associação Brasileira de Normas Técnicas. NBR ISO/IEC 17.025: Requisitos gerais para a competência de laboratórios de ensaio e calibração. Brasil, 2005.

2. ABNT. Associação Brasileira de Normas Técnicas. ISO Guia 35: Materiais de referência - princípios gerais e estatísticos para certificação. Brasil, 2012.

3. ALTMAN, D. G. Practical statistics for medical research. Comparing groups - continuous data. London (UK): Chapman \& Hall, Cap. 9; p. 218-23, 1991.

4. BRITO, N. M. et al. Validação de métodos analíticos: estratégia e discussão. Pesticidas: R Ecotoxicol e Meio Ambiente, v. 13, p. 129-46, 2003.

5. CARDOSO, M. H. W. M. et al. Preparação de um material de referência certificado para o controle de agrotóxicos em hortifrutigranjeiros: estudo da estabilidade. Cien Tecnol Aliment, v. 30, n. 2, p. 439-46, 2010.

6. CASTEJON, M. J. et al. Implementação de controle de qualidade interno (CQI) nos ensaios sorológicos anti-HIV. Produção e distribuição de painéis de soro pelo Instituto Adolfo Lutz Central. BEPA, v. 6, n. 65 , p. 30-2, 2009.

7. CASTEJON, M. J. et al. Implementation of a strategy for improving the serological diagnosis of HIV/AIDS by introducing the internal quality control. Rev Inst Adolfo Lutz, v. 69, n. 2, p.157-64, 2010.

8. CASTEJON, M. J. et al. Avaliação dos múltiplos ciclos de congelamento e descongelamento na estabilidade dos soros para a detecção de anticorpos anti-HIV. Rev Inst Adolfo Lutz, v. 71, n. 3, p.573-581, 2012.

9. ELLISON, S. L. R.; BARWICK, V. J.; FARRANT, T. J. D. Practical statistics for the analytical scientist $-a$ bench guide. Analysis of variance. Cambridge (UK): RSC Publishing, cap. 5-7; p. 48-113, 2009.

10. FAURE, U.; WAGSTAFFE, P. J. Stability of reference materials. Fresenius J Anal Chem, v. 345, n. 1, p. 124-6, 1993.

11. FIPPS, D. R. et al. Effects of multiple freeze thaws and various temperatures on the reactivity of human immunodeficiency virus antibody using three detection assays. J Virol Methods, v. 20, n. 2, p. 127-32, 1988.

12. GABRIEL Jr., A. et al. Validação do sistema de transporte e das dosagens de amostras biológicas enviadas para a central de um laboratório de grande porte.J Bras Patol Med Lab, v. 43, n. 4, p. 235-40, 2007.
13. GISLEFOSS, R. E.; GRIMSRUD, T. K.; MØRKRID, L. Stability of selected serum proteins after long-term storage in Janus Serum Bank. Cin Chem Lab Med, v. 47, n. 5, p. 596-603, 2009.

14. GISLEFOSS, R. E. Quality aspects of long-term stored samples. Studies in the Janus Serum Bank of Norway. 2010. $40 \mathrm{f}$. Doctoral dissertation in Medicine - University of Oslo, Oslo. 2010.

15. INMETRO. Instituto Nacional de Metrologia. Coordenação Geral de Acreditação. Orientações para a seleção e uso de materiais de referência. DOQ-CGCRE-016. Brasil, 2010. Available at: <http://www. inmetro.gov.br/sidoq/arquivos/CGCRE/D0Q/DOQ-CGCRE-16_02.pdf>. Accessed on: 18 Jul. 2012.

16. ISBER. International Society for Biological and Environmental Repositories. Best practices for repositories I: collection, storage, and retrieval of human biological materials for research. Cell Preservation Technology, v. 3, n. 1, p. 5-48, 2005.

17. ISO. International Standards Organization. ISO Guide 34: general requirements for the competence of reference material producers. Geneva, Switzerland, 2009.

18. KIRKWOOD, T. B. L. Predicting the stability of biological standards and products. Biometrics, v. 33, n. 4, p. 736-42, 1977.

19. LINSINGER, T. P. J. et al. Homogeneity and stability of reference materials. Accred Qual Assur, v. 6, n. 1, p. 20-5, 2001.

20. MINISTÉRIO DA SAÚDE. Brasil. Portaria $n^{\circ}$ 686, de 27 de agosto de 1998. Determina o cumprimento das diretrizes estabelecidas das boas práticas de fabricação e controle em estabelecimentos de produtos para diagnóstico in vitro. Available at: <http://www.anvisa.gov.br/legis/ portarias/686_98.htm>. Accessed on: 22 Jun. 2012.

21. SECRETARIA DE ESTADO DA SAÚDE. São Paulo (Estado). Coordenadoria de Controle de Doenças. Manual técnico para implementação do controle de qualidade interno nos procedimentos laboratoriais para diagnóstico sorológico da infecção pelo HIV no estado de São Paulo. São Paulo: IAL; 2007. Available at: <http://bases. bireme.br>. Accessed on: 5 Mar. 2012.

22. SHIH, W. J. et al. Estimating the long-term effects of storage at -70 degrees $\mathrm{C}$ on cholesterol, triglyceride, and HDL-cholesterol measurements in stored sera. Clin Chem, v. 46, n. 3, p. 351-64, 2000.

23. VAN DER VEEN, A. M. H. et al. Uncertainty calculations in the certification of reference materials. 3. Stability study. Accred Qual Assur, v. 6, n. 1, p. 257-63, 2001. 
24. VAUGHT, J. B.; CABOUX, E.; HAINAUT, P. International efforts to develop biospecimen best practices. Cancer Epidemiol Biomarkers Prev, v. 19, n. 4, p. $912-5,2010$.

25. VENELINOV, T.; SAHUQUILLO A. Optimizing the uses and the costs of reference materials in analytical laboratories. Trends Anal Chem, v. 25, n. 5, p. 528-33, 2006.
26. WHO. World Health Organization. Guidelines for using HIV testing technologies in surveillance: selection, evaluation and implementation. Geneva, 2009.

27. ZEGERS, I. et al. Certification report. Certification of proteins in the human serum. Certified reference material ERM - DA470k/IFCC. European Communities, 2008. 